\title{
ТЕОРЕТИЧНІ АСПЕКТИ ПРОФЕСІЙНОЇ ПІДГОТОВКИ МАЙБУТНІХ БАКАЛАВРІВ 3 ТУРИЗМУ
}

\author{
Ольга Дербак \\ викладач кафедри міжнародного туризму, \\ готельно-ресторанного бізнесу та мовної підготовки \\ ВН3 «Університет імені Альфреда Нобеля», \\ м. Дніпро, Україна \\ ORCID ID 0000-0002-6125-4667 \\ derbak.o@duan.edu.ua
}

\begin{abstract}
Анотація. У статті розглянуто окремі теоретичні аспекти професійної підготовки майбутніх бакалаврів 3 туризму. Обгрунтовано актуальність дослідження, 3'ясовано особливості тлумачень фундаментальних понять з обраної теми (туризм, педагогіка туризму, професійна підготовка). Проаналізовано поняття «туризм» і визначено, що це один із найбільш динамічних та перспективних напрямів у сфері послуг, який може стати рушійною силою розвитку України. Установлено, що педагогіка туризму сприяє розвитку туристичної галузі, конкурентоспроможності українського туристичного продукту на внутрішньому та міжнародному ринках туристичних послуг. На основі аналізу документів i науковопрактичних досліджень вітчизняних та зарубіжних науковців розкрито особливості професійної підготовки майбутніх бакалаврів з туризму в закладах вищої освіти України; доведено, що розвиток туристичної галузі вимагає якісної підготовки майбутніх фахівців у закладах вищої освіти України. Наведено висновки та перспективи подальших досліджень.

Ключові слова: професійна підготовка; туризм; педагогіка туризму; бакалавр 3 туризму.
\end{abstract}

Постановка проблеми. Сучасні динамічні темпи євроінтеграції українського суспільства призвели до зміни соціальних установок користувачів різних послуг, зокрема туристичних. На сьогоднішній день споживач висуває високі вимоги щодо туристичних послуг, яких із кожним роком з'являється все більше. Фахівець у сфері туризму повинен надавати якісний сервіс, уміти створити та продати туристичний продукт, працювати в команді та розуміти сучасні тенденції розвитку регіонального та міжнародного туризму й грамотно реалізовувати їх. Тому вивчення теоретичних аспектів, а також дослідження питань оптимізації та вдосконалення професійної підготовки майбутніх бакалаврів 3 туризму в Україні є значущою та актуальною проблемою на сьогодні.

Аналіз основних досліджень і публікацій. Проблеми професійної підготовки фахівців сфери туризму привертають значну увагу дослідників. Так, система підготовки майбутніх бакалаврів 3 туризму в закладах вищої освіти розкрита в дисертаційних дослідженнях Л. Безкоровайної, Н. Бондар,

Професіоналізм педагога: теоретичні й методичні аспекти. - Вип. 12. - Слов’янськ, 2020. 
О. Гальченка, І. Гончарової, О. Дишко, Ю. Земліної, А. Казьмерчук, С. ЛітовкаДеменіної, Є. Маркарян, М. Митник, О. Полякової та інших.

Теоретичні засади педагогіки туризму були предметом досліджень таких учених, як А. Аніщенко та М. Зайцева, П. Бенкендорф і А. Зерер, Т. Джамал та Б. Сміт, М. Джоппе і С. Елліот, Л. Кнодель, Н. Машика та Ю. Машика, Л. Сакун, О. Самохвал, Т. Сокол, В. Федорченко, Н. Фоменко, М. Скрипник і Г. Цехмістрова та ін. Проаналізувавши думки науковців, можемо зробити висновок, що «пріоритетним завданням педагогіки туризму як науки є розкриття закономірностей у галузі виховання засобами туризму, туристичної освіти й навчання, а також управління освітніми й виховними системами» (Самохвал, 2016). Отже, педагогіка туризму сьогодні набуває особливого статусу, бо сприяє забезпеченню розвитку туристичної галузі, конкурентоспроможності українського туристичного продукту на вітчизняному та міжнародному ринках туристичних послуг (Гарбар, 2013), що значно посилює вимоги до його навчання загалом і до системи вищої освіти зокрема.

Формулювання цілей статті. Метою статті $\epsilon$ теоретичний аналіз професійної підготовки майбутніх бакалаврів з туризму, що дасть можливість виявити характерні риси в організації їхнього навчання.

Результати дослідження. Підготовка кваліфікованих фахівців для сфери туризму є важливою складовою української системи вищої освіти, тому що туристична освіта $є$ досить новою в Україні. 3 цього приводу Т. Стоян і К. Цишнатій (2013)зазначають, що сучасність вимагає працівників, що не просто мають освіту, а працівників компетентних, здатних приймати професійні рішення, розв'язувати типові та нетипові проблеми, тим самим забезпечувати високу якість обслуговування й задоволення потреб споживачів.

Глобальні напрями модернізації вищої туристичної освіти, вимоги щодо рівня знань і вмінь фахівців у сфері туризму базуються на провідних концептах, закладених у таких документах, як: Закони України «Про вищу освіту» (2014), «Про туризм» (2015), «Про курорти» (2000), Національна рамка кваліфікацій, Стратегія розвитку туризму та курортів до 2026 року (2019) тощо.

Розглянемо основні аспекти підготовки майбутніх бакалаврів з туризму, які $є$ предметом наукових досліджень багатьох науковців. Зазначимо, що наукові пошуки вчених мають різноманітний характер завдяки популярності та актуальності поняття «туризм».

У Законі України «Про туризм» зазначено: «Туризм - тимчасовий виїзд особи з місця проживання в оздоровчих, пізнавальних, професійно-ділових чи інших цілях без здійснення оплачуваної діяльності в місці, куди особа від'їжджає. Туризм є одним із пріоритетних напрямів розвитку економіки та 
культури, який створює умови для туристичної діяльності» (Закон України «Про туризм», 2015). Тому заклади вищої освіти постійно створюють усе нові освітньо-професійні програми підготовки майбутніх працівників туристичних організацій, ураховуючи водночас важливість туризму для розвитку економіки України.

Необхідно відмітити думку Л. Ткачук (2017), яка констатує, що «туризм як багатоаспектний феномен, який охоплює різні сфери життя людей по всьому світу та характеризується стабільністю і динамічністю, забезпечує вагомий внесок у розвиток людської цивілізації; сприяє формуванню всебічно розвинутої особистості й творчого світосприйняття, що робить його чинником прогресу суспільства». Отже, туризм є одним із найбільш динамічних і перспективних напрямів у сфері послуг, який може стати рушійною силою розвитку України.

Особливої уваги для нас заслуговує «Стратегія розвитку туризму та курортів до 2026 року», яку затверджено Міністерством освіти і науки у 2019 р. Метою стратегії є формування сприятливих умов для активізації розвитку сфери туризму та курортів згідно з міжнародними стандартами якості та з урахуванням європейських цінностей, перетворення її на високорентабельну, інтегровану у світовий ринок конкурентоспроможну сферу, що забезпечує прискорення соціально-економічного розвитку регіонів i держави в цілому, сприяє підвищенню якості життя населення, гармонійному розвитку і консолідації суспільства, популяризації України у світі (Стратегія розвитку туризму та курортів на період до 2026 року, 2019). Проте для реалізації мети Стратегії розвитку туризму та курортів в Україні необхідні компетентні, конкурентоздатні фахівці, які повинні мати «належний рівень професійної підготовки, високий рівень сформованості загальних та професійних компетентностей, досвід виконання професійних функцій, надійні світоглядні, моральні та політичні орієнтири у всіх сферах його діяльності, зокрема фаховій» (Устименко, 2017); здатні розвинути український туризм до висот міжнародного рівня. Тому зараз туристичній індустрії потрібні професійно підготовлені фахівці.

У межах основних принципів Болонського процесу сертифікація стандартів якості UNQTO EdQual залишається важливою діяльністю освітніх установ, ця сертифікація була розроблена і впроваджена Всесвітньою організацією туризму (World Tourism Organization) для підвищення якості освіти в галузі туризму i його ефективності загалом. Це дозволяє визначити конкурентоспроможність освітніх програм, які реалізуються закладами вищої освіти, і їхня відповідність міжнародним стандартам якості (Abishova, Kydyrovab, Urazbaevac, Abishovad, Asan, 2014). На нашу думку, українські заклади вищої освіти, які здійснюють підготовку фахівців у сфері туризму

Професіоналізм педагога: теоретичні й методичні аспекти. - Вип. 12. - Слов’янськ, 2020. 
повинні переглянути своє ставлення до формування та розвитку нових державних освітніх стандартів і впровадити нові методи навчання, відповідні міжнародній практиці.

Аналіз Національного класифікатора професій України (ДК 003:2010) засвідчує, що бакалавр з туризму здатний виконувати професійну роботу і може займати відповідну первинну посаду за категорією: інструктор-методист 3 туризму, екскурсовод, інструктор оздоровчо-спортивного туризму (за видами туризму), організатор подорожей (екскурсій), організатор туристичної i готельної діяльності, фахівець із розвитку сільського туризму, фахівець із туристичного обслуговування, фахівець із конференц-сервісу, фахівець 3 організації дозвілля, фахівець із спеціалізованого обслуговування, фахівець із туристичної безпеки, фахівець із гостинності (готелі, туристичні комплекси та ін.), інспектор з туризму, агент з організації туризму, офісний службовець (подорожі), екскурсознавець, туризмознавець, інструктор-методист з туризму) (Постанова Кабінету Міністрів України, 2011). Отже, треба акцентувати увагу на багатопрофільному характері туристичної освіти, яка «готує кадри різних спеціальностей i напрямків економічного, технічного, технологічного, управлінського, наукового й інших профілів» (Аніщенко, Зайцева, 2015).

Здійснений аналіз документів свідчить про те, що розвиток туристичної галузі вимагає якісної підготовки майбутніх фахівців у закладах вищої освіти України. Аналіз наукової літератури дозволив Н. Пангеловій і Б. Пангелову (2016) виділити й уточнити напрямки сучасних досліджень, проблем професійної підготовки майбутніх фахівців сфери туризму в Україні: дослідження сутності та структури активного відпочинку; дослідження змісту і структури туристсько-спортивної діяльності; дослідження і розробка змісту професійної туристсько-спортивної підготовки фахівців туристичної сфери; пошук ефективної моделі підготовки майбутніх фахівців різних груп, професій туристичної спрямованості; визначення специфіки підготовки студентів для сфери туризму в контексті оздоровчо-спортивного туризму.

Доволі близькою в контексті нашого дослідження вважаємо наукову ідею М. Черезової (2010), яка зазначає, що сучасна система професійної освіти майбутніх фахівців сфери туризму орієнтована на створення фундаменту для становлення студента як майбутнього професіонала, якому притаманні компетентність, висока духовна культура, мобільність, уміння вільно орієнтуватися в новітніх досягненнях науки та практики, високий рівень розвитку морально-етичних якостей і професійної етики. За таких умов суттєво підвищуються вимоги до формування таких якостей особистості майбутніх фахівців сфери туризму, як професіоналізм, відповідальність, ініціативність, 
комунікабельність, креативність, моральність.

Вивчаючи особливості професійної підготовки майбутніх бакалаврів 3 туризму, науковці одними із актуальних завдань сучасної професійної педагогіки визначають необхідність формування світоглядної концепції фахівця, у межах якої закладаються основи професійного, економічного і логіко-інформаційного мислення, накопичуються необхідні знання, виробляються навички і вміння (Сокол, 2008); орієнтації на потреби розвитку людини і надання йому можливості більш ефективної участі у світі праці (Зорін, 2001); використання методичного досвіду і навчальних програм профільних зарубіжних закладів освіти, які протягом багатьох років успішно працюють на освітньому ринку в Європі; забезпечення багатоступінчастої, безперервної системи підготовки та підвищення кваліфікації кадрів для індустрії туризму, основною метою якої буде інтеграція освіти та практики; встановленням співпраці, контактів, взаємодій із різними підприємствами туристської спрямованості (готелі, ресторани, туристичні агентства, іншими заклади освіти тощо) у формі зустрічей-семінарів, круглих столів, присвячених актуальним проблемам розвитку галузі, що допоможе зорієнтувати освітньо-професійні програми на потреби туристських підприємств; наявності сучасного матеріально-технічного оснащення вищих закладів освіти, яке наразі не завжди знаходиться на належному рівні (Лапшина, 2009). Так, підвищення якості професійної підготовки майбутніх бакалаврів 3 туризму залежить від безлічі факторів.

Цінною вважаємо думку Т. Зубехіною (2014), що наявна до цього часу система підготовки фахівців із туризму була насамперед пов'язана 3 підвищенням їхньої кваліфікації, проте такі заходи без фундаментальної освіти не розв'язують кадрової проблеми. Учена зазначає, що з'являються суперечності між потребами туристичної галузі у висококваліфікованих фахівцях та іншими реаліями їхньої підготовки в Україні. Їхнє розв'язання активізує питання аналізу сучасних проблем професійної підготовки майбутніх фахівців із туризму в закладах вищої освіти України. Отже, за таких умов суттєво підвищуються вимоги до різних аспектів підготовки майбутніх фахівців сфери туризму, зокрема такої, як підготовка до професійної взаємодії.

Проблема вдосконалення системи професійної освіти в туризмі, на думку О. Самохвал (2016), зумовлена сучасними вимогами, які висуваються до фахівців із туризму роботодавцями, споживачами туристичних послуг, конкуренцією на ринку праці, який стає все більш вимогливим до фахівців із туризму, навчання яких має забезпечувати високий рівень їхньої теоретичної та практичної підготовки, готовність до здійснення професійної взаємодії зі споживачами туристичних послуг. Тому серед пріоритетних завдань професійної

Професіоналізм педагога: теоретичні й методичні аспекти. - Вип. 12. - Слов’янськ, 2020. 
Теоретичні аспекти професійної підготовки майбутніх бакалаврів з туризму

підготовки майбутніх бакалаврів 3 туризму виділяємо такі: підготовка конкурентоспроможного фахівця; формування прагнення досягти високого рівня професіоналізму; удосконалення професійної підготовки на основі сучасних інноваційних технологій; розвиток ініціативи і творчої активності майбутніх фахівців на підставі партнерських відносин; розвиток толерантності, культури спілкування і поведінки в міжкультурній професійній взаємодії.

Здійснений аналіз літератури свідчить про те, що розвиток туристичної галузі вимагає якісної підготовки майбутніх фахівців у закладах вищої освіти України.

Висновки. Так, сучасний туристичний ринок вимагає від фахівців сфери туризму високого рівня професійно-практичної підготовки як запоруки конкурентоспроможності та кар'єрного розвитку. Тому пріоритетним завданням професійної підготовки майбутніх бакалаврів 3 туризму $\epsilon$ сформувати майбутнього фахівця зі стратегічним способом мислення, професійними знаннями в галузі туризму, здатних ідентифікувати та вирішувати складні професійні завдання та практичні проблеми. Здійснений аналіз професійної підготовки майбутніх бакалаврів 3 туризму не претендує на вичерпність. Перспективною залишається проблема наповненості змісту навчання вказаних фахівців.

\section{СПИСОК ВИКОРИСТАНИХ ДЖЕРЕЛ}

1. Аніщенко А. П., Зайцева М. М. (2015). Підготовка кадрів туристичної індустрії. Збірник наукових працьь Хмельницького інституту соичіальних технологій Університету «Україна», 11, 39-43.

2. Гарбар Г. А. (2013). Підготовка фахівців сфери туризму у вищих навчальних закладах України. Вісник Харківського національного педагогічного університету імені Г.С. Сковороди. Філософія, 41(1), 246-257.

3. Зубехіна, Т. В. (2014). Теоретична розробка проблеми формування інформаційної культури бакалаврів з туризму у процесі фахової підготовки. Сучасні інформаційні технології та інноваційні методики навчання у підготовичі фахівців: методологія, теорія, досвід, проблеми, 38, 268-271.

$\begin{array}{lllll}\text { 4. Закон України «Про туризм» } & \text { (2015). }\end{array}$ https://zakon.rada.gov.ua/laws/show/324/95-\%D0\%B2\%D1\%80.

5. Зорин, И. В. (2001). Теоретические основы формирования содержания профессионального туристического образования. (Дис. докт. пед. наук). Москва, Российская Федерация.

6. Лапшина, А. Г. (2009). Основные проблемы подготовки профессиональных кадров для индустрии туризма. Матер. всеросс. науч.-практич. конф. Оренбург, Россия: 3194-3197.

7. Пангелова Н. Е., Пангелов Б. П. (2016). Проблемы профессиональной подготовки будущих специалистов в учебных заведениях туристической отрасли Украины: анализ научных исследований. Курорты. Сервис. Туризм, 1(30), 129-133.

8. Постанова Кабінету Міністрів України від 23 листопада 2011 р. № 1341 «Про затвердження Національної рамки кваліфікацій» (б.д.). Взято 3 http://zakon1.rada.gov.ua/laws/show/1341-2011-п\#n37. 


\title{
О. ДЕРБАК
}

Теоретичні аспекти професійної підготовки майбутніх бакалаврів з туризму

9. Самохвал, О. О. (2016). Теоретичні основи змісту професійної підготовки майбутніх фахівців туристичної галузі у ВНЗ України. Молодий вчений, 11(38), 497-501.

10. Сокол, Т. Г. (2008). Педагогічні аспекти створення моделі спеціаліста туристичного менеджменту та науково-методичного забезпечення його підготовки. Вісник Черкаського Національного університету імені Богдана Хмельницького, 137, 57-60.

11. Стоян, Т., Цишнатій, К. (2013). Підготовка кадрів для туристичної галузі в сучасній Україні. Науковий часопис Національного педагогічного університету імені М.П. Драгоманова. Історичні науки, 10, 276-284.

12. Стратегія розвитку туризму та курортів на період до 2026 року. (2019). Взято 3 https://zakon.rada.gov.ua/laws/show/168-2017-\%D1\%80.

13. Ткачук, Л. (2017). Сутність туризму як багатоаспектного суспільного явища. Вісник Киівського начіонального університету імені Тараса Шевченка, 1(66), 109-113.

14. Устименко, Ю. С. (2017). Підготовка майбутніх стоматологів до професійної взаємодії засобами інтерактивних методів навчання. (Дис. канд. пед. наук). Дніпро, Україна.

15. Черезова, М. В. (2010). Формування культури професійного спілкування майбутніх фахівиів сфери туризму у навчально-виховному процесі коледжу. (Автореф. дис. канд. пед. наук). Луганськ, Україна.

16. Abishova, N., Kydyrovab, Zh., Urazbaevac, G., Abishovad, A., \& Asan, D. (2014). Good Opportunities in Training of Personnel for Travel Industry. Social and Behavioral Sciences, 143, 445-449.

17. World Tourism Organization. United Nations specialized agency. (n. d.). Retrieved from https://www.unwto.org/.

\section{THEORETICAL ASPECTS OF THE PROFESSIONAL TRAINING OF FUTURE BACHELORS IN TOURISM}

\author{
Olha Derbak \\ Lecturer at the Department of International Tourism, Hotel and Restaurant Business \\ and Language Training \\ Alfred Nobel University, Dnipro, Ukraine \\ ORCID ID 0000-0002-6125-4667 \\ derbak.o@duan.edu.ua
}

\begin{abstract}
At the present stage of the development of Ukrainian society, the requirements for staffing of the tourism industry are increasing. Therefore, a high level of training of future bachelors in tourism can ensure the proper competitiveness of the Ukrainian tourism product. The research on the training of future bachelors in tourism in higher education institutions is given considerable attention. The following aspects are relevant: the system of training future bachelors in tourism in higher education institutions; theoretical principles of tourism pedagogy, etc. The analysed works reveal the problems of organization of the educational process, which require optimization of professional training of future specialists in the field of tourism.

The concept of "tourism" is analyzed and it is determined that it is one of the most dynamic and promising directions in the sphere of services. It is established that the pedagogy of tourism contributes to the development of the tourism industry, the competitiveness of the Ukrainian tourism product in the domestic and international markets of tourist services, which significantly increases the requirements for its education as a whole and to the higher education system in particular. The results of the analysis of the National Classifier of Professions of Ukraine has shown that the bachelor of tourism can hold a corresponding primary position in different categories, which testifies to the multidisciplinary nature of tourism education, which trains specialists in different specialties and areas of economic, technical, technological, managerial, scientific and other profiles. The
\end{abstract}

Професіоналізм педагога: теоретичні й методичні аспекти. - Вип. 12. - Слов'янськ, 2020. 


\section{О. ДЕРБАК}

Теоретичні аспекти професійної підготовки майбутніх бакалаврів з туризму

peculiarities of professional training of future bachelors in tourism in higher education institutions of Ukraine are revealed.

Key words: professional training; tourism; pedagogy of tourism; bachelor of tourism.

\section{REFERENCES}

1. Anishchenko, A. P. \& Zaitseva, M. M. (2015). Training of tourism industry staff. Zbirnyk naukovykh prats Khmelnytskoho instytutu sotsialnykh tekhnolohii Universytetu "Ukraina”, 11, 3943.

2. Hrabar, H. A. (2013). Training of tourism specialists in higher educational establishments of Ukraine. Visnyk Kharkivskoho natsionalnoho pedahohichnoho universytetu imeni H.S. Skovorody. Filosofiia, 41(1), 246-257.

3. Law of Ukraine "On Tourism". (2015). Retrieved from https://zakon.rada.gov.ua/laws/show/324/95-\%D0\%B2\%D1\%80

4. Zabukhenina, T. V. (2014). Theoretical development of the problem of forming the information culture of bachelors in tourism in the process of professional training. Suchasni informatsiini tekhnolohii ta innovatsiini metodyky navchannia u pidhotovtsi fakhivtsiv: metodolohiia, teoriia, dosvid, problem, 38, 268-271.

5. Zorin, I. V. (2001). The theoretical basis for the formation of the content of professional tourism education. (Doctor's thesis) Moscow, the Russian Federation.

6. Lapshina, A. H. (2009). The main problems of training professional personnel for the tourism industry. Materialy vserossiiskoi nauchno-prakticheskoi konferentsii. Orenburh, 3194-3197.

7. Panhelova, N. E. \& Panhelova, B. P. (2016). Problems of professional training of future specialists in educational institutions of the tourism industry of Ukraine: analysis of scientific research. Kurorty. Servis. Turizm, 1(30), 129-133.

8. Decree of the Cabinet of Ministers of Ukraine of November 23, 2011, No. 1341 "On Approval of the National Qualifications Framework". Retrieved from http://zakon1.rada.gov.ua/laws/show/1341-2011-п\#n37

9. Samokhval, O. O. (2016). Theoretical bases of the content of professional training of future specialists of tourism industry in universities of Ukraine. Molodyi vchenyi, 11(38), 497-501.

10. Sokol, T. H. (2008). Pedagogical aspects of creation of model of specialist of tourist management and scientific and methodological support of its preparation. Visnyk Cherkaskoho Natsionalnoho universytetu imeni Bohdana Khmelnytskoho, 137, 57-60.

11. Stoian, T. \& Tsyshnatii, K. (2013). Training for tourism industry in modern Ukraine. Naukovyi chasopys Natsionalnoho pedahohichnoho universytetu imeni M.P. Drahomanova. Istorychni nauky, 10, 276-284.

12. Tourism and resort development strategy for the period until 2026. (2019). Retrieved from https://zakon.rada.gov.ua/laws/show/168-2017-\%D1\%80

13. Tkachuk, L. (2017). The essence of tourism as a multidimensional social phenomenon. Visnyk Kyivskoho natsionalnoho universytetu imeni Tarasa Shevchenka, 1(66), 109-113.

14. Ustymenko, Yu. S. (2017). Preparing future dentists for professional interaction through interactive teaching methods. (Candidate's thesis). Dnipro, Ukraine.

15. Cherezova, M. V. (2010). Forming a culture of professional communication for future tourism professionals in the college's educational process. Luhansk, Ukraine.

16. Abishova, N., Kydyrovab, Zh., Urazbaevac, G., Abishovad, A., \& Asan, D. (2014). Good Opportunities in Training of Personnel for Travel Industry. Social and Behavioral Sciences, 143, 445-449.

17. World Tourism Organization. United Nations specialized agency. (n. d.). Retrieved from https://www.unwto.org/

Матеріали надійшли до редакції 19.03.2020 p. 